\title{
The mid-term results of treatment for tibial pilon fractures
}

\author{
Tibia pilon kırıklarında orta dönem cerrahi sonuçlarımız
}

\author{
Deniz GÜLABİ, ${ }^{1}$ Özgür TOPRAK, ${ }^{1}$ Cengiz ŞEN, ${ }^{2}$ \\ Cem Coşkun AVCI, ${ }^{1}$ Erkal BİLEN, ${ }^{3}$ Fevzi SAĞLAM ${ }^{1}$
}

\section{BACKGROUND}

In this report, the surgical treatment results of distal tibia (pilon) fractures are analyzed radiologically and clinically.

\section{METHODS}

Between 2002 and 2009, 32 feet of 31 patients (25 males, 6 females; mean age 46 years; range 17 to 72 years) who were treated surgically for tibial pilon fractures were evaluated. Open reduction and internal fixation were applied to 24 and external fixation to 8 fractures. The patients were evaluated according to the Teeny-Wiss functional ankle score, and overall assessment of reduction was calculated radiographically according to the criteria of Ovadia and Beals.

\section{RESULTS}

While excellent results were achieved in 9 (47.4\%) type 2,5 type $1(26.3 \%)$, and $5(26.3 \%)$ type 3 fractures, fair/ poor outcomes were obtained in $9(69.2 \%)$ type 3 and in 2 $(15.4 \%)$ types 1 and 2 fractures each $(p<0.015)$. Compared to the external fixation application, a statistically significantly higher number of excellent and good outcomes were obtained with open reduction internal fixation application $(\mathrm{n}=3,15.8 \%$ vs $\mathrm{n}=16,84.2 \%$, respectively; $\mathrm{p}<0.05)$.

\section{CONCLUSION}

If the principles of atraumatic soft tissue dissection, anatomic reduction of the joint face, stable fixation, and early mobilization of the patient are complied with in the surgical treatment of pilon fractures, successful results can be achieved. However, in type 3 fractures, even if these principles are complied with, post-traumatic arthritis is inevitable.

Key Words: Rüedi-Allgöwer classification; surgical treatment; tibial pilon fractures.

\section{$\boldsymbol{A M A C}$}

Bu yazıda, distal tibia (pilon) kırıklarının cerrahi tedavi sonuçları, radyolojik ve klinik olarak araştırıldı.

\section{GEREÇ VE YÖNTEM}

2002-2009 tarihleri arasında cerrahi olarak tedavi edilen 31 hastanın (25 erkek, 6 kadın; ortalama yaş 46; dağılım 17-72 yaş) 32 ayağı değerlendirildi. Bu kırıkların 24'üne açık redüksiyon ve internal fiksasyon, 8'ine eksternal fiksasyon yapıld1. Hastalar ortalama 46 ay takip edildi. Hastalar Teeny-Wiss fonksiyonel ayakbileği skorlamasına göre değerlendirildi. Radyolojik olarak kırık redüksiyon skorlaması Ovadia ve Beals kriterlerine göre yapıldı.

\section{BULGULAR}

Tip 2 kırıkların 9'unda $(\% 47,4)$, tip 1 kırıkların 5'inde $(\% 26,3)$ ve tip 3 kırıkların 5 'inde $(\% 26,3)$ mükemmel sonuç elde edildi. Tip 3 kırıkların 9'unda $(\% 69,2)$ kötü sonuç elde edilmişken, tip 1 ve tip 2 kırıkların 2'sinde $(\% 15,4)$ kötü sonuç elde edildi. Eksternal fiksatör uygulaması ile karşılaştırıldığında, çok iyi ve iyi sonuçlar anlamlı derecede yüksek sayıda açık redüksiyon internal fiksasyon uygulaması ile elde edildi (sırasiyla, $n=3, \% 15,8$ ve $n=16$, $\% 84,2 ; \mathrm{p}<0.05)$.

\section{SONUÇ}

Pilon kırıklarının cerrahi tedavisinde, atravmatik yumuşak doku diseksiyonu, eklem yüzünün anatomik redüksiyonu, stabil bir tespit, erken hareket ve hastanın mobilizasyonu ilkelerine uyulduğunda başarılı sonuçlar alınabilmektedir, ancak bu prensiplere uyulmasına rağmen tip 3 kırıklarda travma sonrası artrit kaçınılmazdır.

Anahtar Sözcükler: Rüedi-Allgower sınıflaması; cerrahi tedavi; pilon tibia kırıkları.
${ }^{1}$ Dr. Lütfi Kırdar Kartal Eğitim ve Arastırma Hastanesi,

1. Ortopedi ve Travmatoloji Kliniği, İstanbul; ${ }^{2}$ Bezmi Alem Üniversitesi, Ortopedi ve Travmatoloji Kliniği, İstanbul; ${ }^{3}$ Memorial Hastanesi, Ortopedi ve Travmatoloji Kliniği, İstanbul. 
Recently, the frequency of distal tibia intraarticular fractures has increased rapidly. A pilon fracture of the tibia involves the horizontal articular surface of the distal tibia with proximal extension. The main reasons are industrialization, prevalence of sports activities, and increase in domestic and traffic accidents. The pilon fracture is an intraarticular fracture of the lower end of the tibia and can be associated with various degrees of collapse and disintegration on the joint surface. One percent of lower extremity fractures and $7-10 \%$ of all tibia fractures are pilon fractures. ${ }^{[1-3]}$

The usual mechanism of injury is axial loading of the limb through the ankle, with or without torsional load. ${ }^{[1,3,4]}$ For the management of pilon fractures, various methods are recommended, such as manipulation and plaster application, external fixation, vertical transarticular and percutaneous pin fixation of large fragments and plaster application, stabilization of the fibula, open reduction and internal fixation (ORIF) to both tibia and fibula, primary arthrodesis, and even amputation. However, the most commonly used method is the ORIF approach. ${ }^{[2,4-6]}$ External fixation of intraarticular fractures relies on distraction. ${ }^{[2]}$

In the literature up to 1969 , good results for pilon fractures were achieved in fewer than $50 \%$. After Rüedi and Allgöwer introduced their open reduction techniques in 1969 , they reported $71 \%$ good and excellent results for their four-year study. Heim and Naser $^{[7]}$ reported $90 \%$ good and excellent results in another study.

The reason for the increase in good and excellent results is compliance to the ORIF principles introduced by Rüedi and Allgöwer. The operation consists of four surgical steps. 1-Reduction and fixation of the fibula, 2- Reconstruction and fixation of the tibia joint, 3-Filling of the metaphysical defect, which remains after the reconstruction of the joint, with autogenous spongious bone graft, and 4- Application of a support plate in order to prevent varus deformity, which might occur at a later stage. ${ }^{[2,8-14]}$

In this study, the mid-term results of the ORIF method, which we applied to 31 patients with pilon tibia fractures, were evaluated in light of the literature.

\section{MATERIALS AND METHODS}

Between 2002 and 2009, we studied 32 ankles of 31 patients (25 [81.25\%] males, 6 [18.75\%] females) in our clinic. Two senior attending surgeons treated all cases. Medical records, operative notes, and radiographs were reviewed by a surgeon not involved in the care of the patients. They had been operated with the established diagnosis of pilon tibia fracture and presented regularly for follow-ups. The extremity distribution of the cases was as follows: 19 right
Table 1. Distribution of accompanying injuries to pilon fractures

\begin{tabular}{lc}
\hline Accompanying injuries & Case number \\
\hline Vertebra fracture & 4 \\
Calcaneus fracture & 1 \\
Scaphoid fracture & 1 \\
Radius fracture & 1 \\
Proximal tibia fracture & 1 \\
Patella fracture & 1 \\
Cuneiform fracture & 1 \\
Fibula fracture & 1 \\
\hline
\end{tabular}

(61.3\%), 11 left (35.4\%) and 1 bilateral (3.3\%). The youngest patient in our study population was 17 years old, and the oldest was 72 years old, with a mean age of 46 years. When the etiology of the traumas was considered, there were $18(58 \%)$ falls from a height, 9 (29\%) simple falls and 4 traffic accidents (13\%). Thirteen of 32 patients with pilon fractures had open fractures. According to Gustilo-Anderson classification, our open fractures were of type $1(n=3 ; 23 \%)$, type $2(\mathrm{n}=7 ; 53.9 \%)$, and type $3(\mathrm{n}=3 ; 23 \%)$, respectively. Twenty of our patients had $21(65.6 \%)$ fibula lower end fractures. In 9 of our patients, there were 11 additional orthopedic pathologies (Table 1).

For five of these accompanying additional pathologies $(45 \%)$, a surgical operation was applied, and the rest $(55 \%)$ received conservative treatment. Mean hospitalization period of our patients was 15.8 (5-44) days. In the preoperative evaluation, standard anteroposterior (AP) and lateral ankle radiographs and computerized tomographic (CT) images of the affected ankle were obtained. The fractures were categorized according to Rüedi-Allgöwer fracture classification. According to this classification, 7 type 1 (21.8\%), 11 type $2(34.2 \%)$ and 14 type $3(44 \%)$ pilon fractures were treated.

First, the skin condition of the patients hospitalized with a tibia pilon fracture was evaluated and their neurovascular examinations were made. Then, radiological examinations were performed. Skeleton traction from the calcaneus was applied to all patients with type 3 fractures, to 5 cases with type 2 and to 4 cases with type 1 fractures, and the affected ankles were supported with a Braun's brace. Traction was not applied to the patients with minimal soft tissue damage; they were instead placed into a brace with ample cotton pad support, their affected knees were elevated, and ice compression was applied. In patients with open fractures, we applied debridement and serum isotonic irrigation in the operating room as soon as possible. We applied prophylaxis to prevent the development of tetanus and gaseous gangrene. For type 1 open fractures, we initiated treatment with a 1 st gen- 

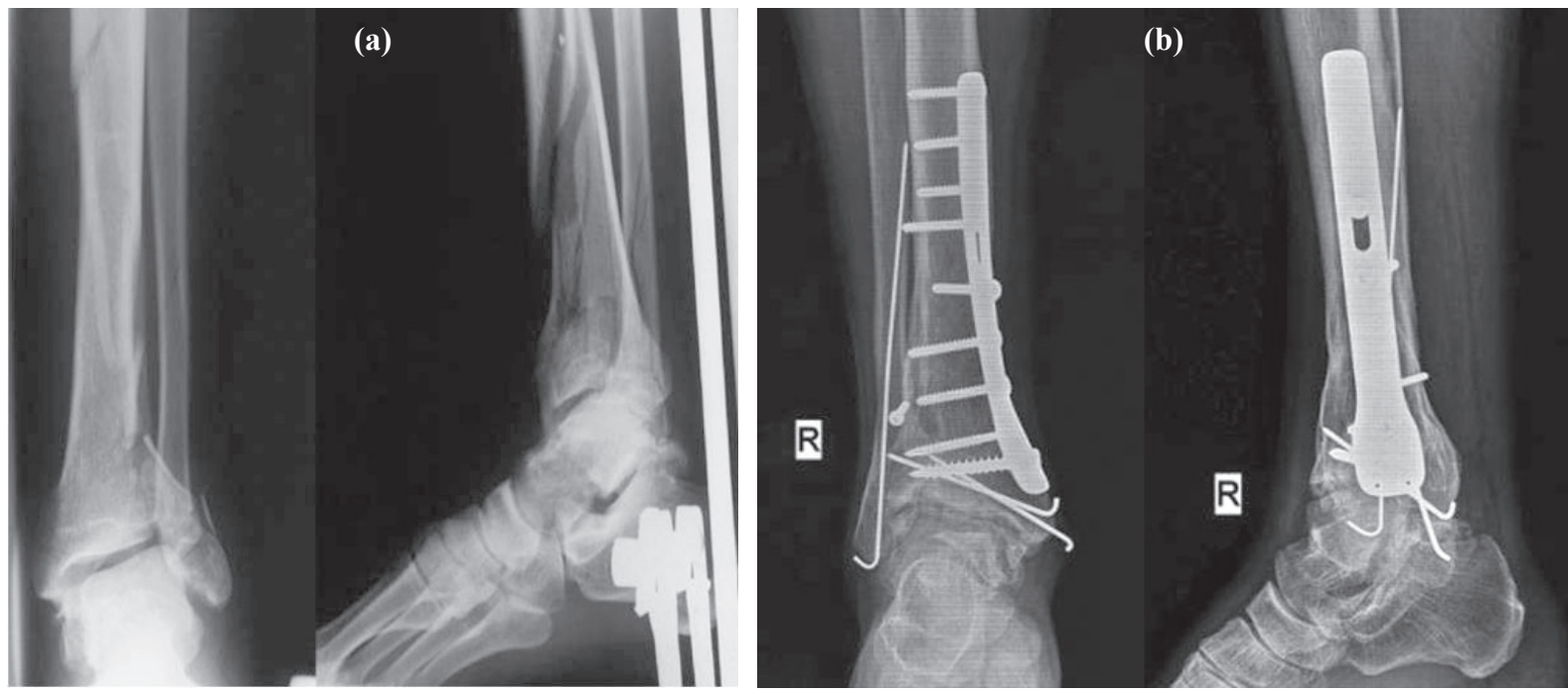

Fig. 1. (a) X-rays showing a comminuted tibial pilon fracture extending to the diaphysis in a 49-year-old man with type 3 fracture, who was operated on the 11th day postinjury. (b) X-rays of the same patient after internal fixation with the use of plate and screws.

eration cephalosporin (cephazolin sodium; $1 \mathrm{~g}$ intravenous [iv]), while for type 3 open fractures, we started gentamicin (160 mg intramuscular [im] x 5 days) and metronidazole (500 $\mathrm{mg}$ iv $\mathrm{x} 3$ days) therapy additionally. After regression of the foot and ankle edema and preoperative anesthesia examinations, the patients were taken to surgery. Mean time from the hospitalization to the operation was 10.7 days (1-28 days). For 32 pilon fractures, ORIF $(\mathrm{n}=24 ; 75 \%)$ and external fixation $(n=8 ; 25 \%)$ were performed.

\section{Surgical Technique}

During the surgical procedures performed on 21 patients with a fibula fracture, firstly fibula fixation was applied to gain length according to the surgical technique suggested by Rüedi-Allgöwer. To fix the fibula, $1 / 3$ tubular plate $(n=9 ; 42.8 \%)$, intramedullary wire $(n=8 ; 38.3 \%)$, dynamic compression $(n=3$; $14.2 \%)$, and semitubular plate $(n=1 ; 4.7 \%)$ were used.

ORIF was performed for tibias using an anterolateral $(\mathrm{n}=2)$, anteromedial $(\mathrm{n}=19)$, or short anterior $(n=3)$ approach. The surgeons tried to leave at least 7 $\mathrm{cm}$ of healthy skin tissue between two incisions. After reconstruction of the tibia joint surface, osteosynthesis was applied using K-wires, cancellous screws or cannulated screws. Stabilization of 3 pilon fractures of 2 patients was achieved with these methods of osteosynthesis. In 21 fractures extending to the metaphysis, plates were applied because of inadequate fixation. For tibial fixations, a cloverleaf plate $(\mathrm{n}=2 ; 9.5 \%)$, or distal tibia lateral $(n=2 ; 9.5 \%)$ or medial $(n=17 ; 81 \%)$ compatible anatomic plates were used. Due to a metaphyseal defect, grafts were applied to 12 patients. After the scope examination of the fracture site, the previously applied tourniquet was opened, hemostatic controls were made, and a Hemovac drain was applied. The drain was removed on the 2 nd postoperative day. The short leg brace was left in place. After postoperative regression of foot and ankle edema, active leg range of motion (ROM) exercises were started. In the 6th week, the patient was allowed to perform partial and at the end of the 3rd month full load-bearing exercises.

External fixation was applied to 4 patients with second- and third-degree open fractures and to 4 patients whose comminuted fractures could not be fixed using internal fixation materials. The ankle joints of 6 of these patients were explored anteriorly with a $3 \mathrm{~cm}$ incision. For 4 patients, large fragments were reduced, fixed by means of K-wire, cannulated screws and spongious screws, and minimal osteosynthesis was applied. Afterwards, three pieces of $5 \mathrm{~mm}$ cortical nails were placed in the tibia and three pieces of $4 \mathrm{~mm}$ spongious nails in the calcaneus, and then an Orthofix type monolateral external fixator was applied. The other 2 patients were treated with the Ilizarov joint distraction method after fixation of the fibula without applying osteosynthesis to achieve the correct alignment. Before the surgery, all patients were given $1 \mathrm{~g}$ cephazolin iv injection. The same postoperative antibiotherapy was continued for 3 days as daily injections $x 3$. After the first day of their hospitalizations, the patients received low molecular weight heparin (LMWH) prophylaxis until the 5th postoperative day. The patients managed with external fixation were mobilized with the aid of two crutches on the 1st day postoperatively. After documentation of radiological synostosis (approximately 16 weeks postoperatively), the fixator was removed and full load-bearing was allowed. The patients with a circular type fixator were mobilized on the 1st day postoperatively with full load-bearing status. 

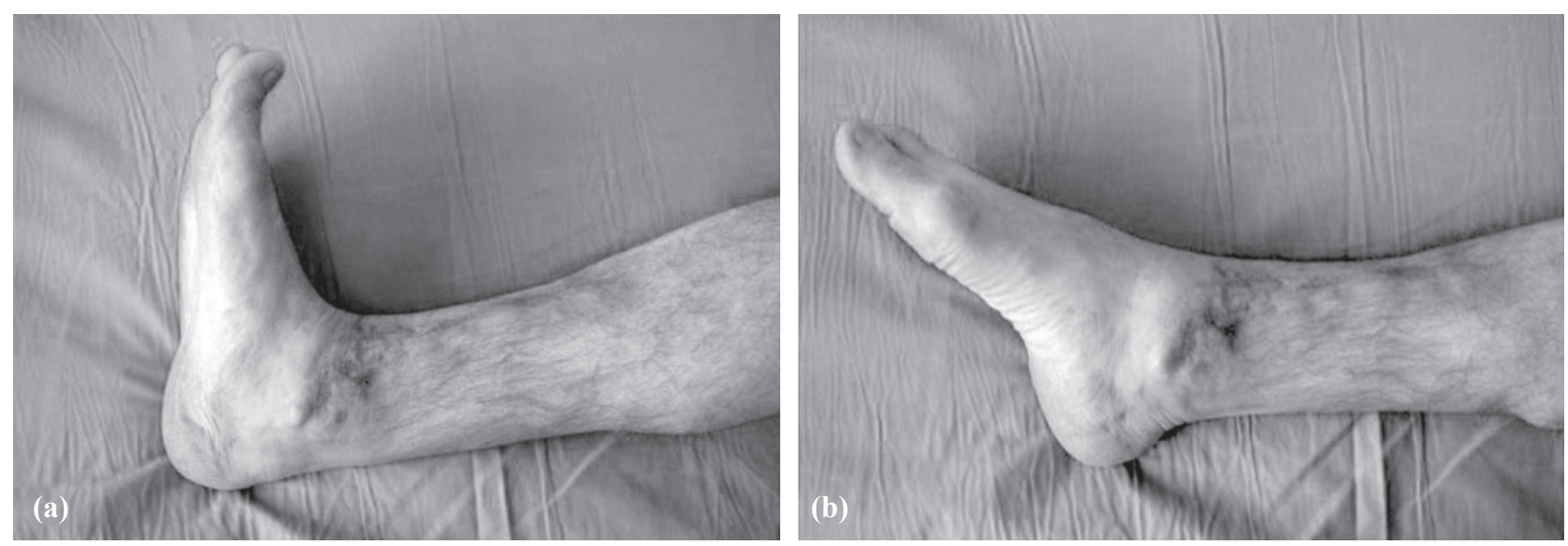

Fig. 2. Clinical pictures of the same patient showing good ankle joint range of motion: dorsiflexion (a) and plantar flexion (b).

The foot rings of the patients were removed in approximately the 10th week postoperatively. The operated ankle was mobilized. At approximately the 16th week, after the observation of callus formation radiologically, the fixator was removed (Figs. 1a, b and 2a, b).

\section{RESULTS}

The patients were evaluated according to the Teeny-Wiss ankle symptom and functional ankle scores. In this protocol, the evaluation was made by comparing the healthy ankle with a damaged ankle. According to these criteria, 32 pilon tibia fractures of 31 patients, who were monitored regularly, were evaluated. These patients were followed-up for an average of 46 months (8-97 months). In all of our patients, we achieved osseous union without a second intervention. The mean time to union was 16 weeks (10-25 weeks). According to the evaluation criteria, excellent $(n=4 ; 12.5 \%)$, $\operatorname{good}(n=15 ; 46.8 \%)$, fair $(n=6 ; 18.9 \%)$, and poor $(n=7$; $21.8 \%$ ) outcomes were obtained. The radiographs obtained at the last follow-up were reviewed for union, loss of fixation, malunion, nonunion, and also for the quality of reduction according to Ovadia and Beals criteria. The results are listed in Table 2.

Table 2. The mid-term results of the treatment for tibial pilon fractures

\begin{tabular}{lccccc}
\hline & & \multicolumn{4}{c}{ Quality of reduction by fracture type } \\
\cline { 3 - 6 } $\begin{array}{l}\text { Fracture } \\
\text { type }\end{array}$ & $\begin{array}{c}\text { Patient } \\
\text { no }\end{array}$ & Anatomic & Good & Fair & Poor \\
\hline 1 EF & 1 & 0 & 1 & 0 & 0 \\
1 ORIF & 6 & 4 & 2 & 0 & 0 \\
2 EF & 2 & 0 & 2 & 0 & 0 \\
2 ORIF & 9 & 5 & 4 & 0 & 0 \\
3 EF & 5 & 0 & 2 & 2 & 1 \\
3 ORIF & 9 & 0 & 7 & 2 & 0 \\
\hline EF Exyyyyyy
\end{tabular}

EF: External fixation; ORIF: Open reduction and internal fixation.
We did not detect any inadequacy of fixing material as a complication in our patients. No case of pseudoarthrosis or varus collapse was seen in any of our patients. Skin necrosis developed on the postoperative wounds of 1 case with a closed Rüedi-Allgöwer type 1 fracture and 1 case with Rüedi-Allgöwer type 3 and Gustilo-Anderson type 2 open fractures. These skin wounds were treated and healed with local dressing without the necessity of surgical intervention. In 4 of our patients, an infection developed on the postoperative wound. Three of these 4 patients with superficial infections had type 2 and 1 of them had type 3 open fractures. These patients were treated and healed with surface wound treatment and antibiotherapy without the necessity of a revision operation. In 1 patient, a deep infection developed at a later stage. This patient had Rüedi-Allgöwer type 3 and Gustilo-Anderson type 1 open fracture. The fixing material was extracted from the patient. Debridement and antibiotherapy were applied. The patient recovered without any sequela. Sudeck's atrophy in $6(18.75 \%)$, late-term synostosis in $3(9 \%)$, and post-traumatic arthrosis in $7(21.8 \%)$ of our patients developed postoperatively. Our patients with Sudeck's atrophy healed using physiotherapy. Those with post-traumatic arthritis were monitored and informed about arthrodesis later. However, no additional surgery was performed in any of our patients.

\section{DISCUSSION}

Pilon fractures generally occur after high energy traumas, and significant soft tissue injury is frequently present. ${ }^{[1-3]}$ For these fractures, the severity of the trauma, inadequacy of local blood circulation, frequency of complications, and the high risk of becoming disabled have to be considered. ${ }^{[1,2,6]}$

Etter and Ganz ${ }^{[15]}$ studied 41 patients with pilon fractures, and stated that sport traumas are the most common etiologic factor. In his series with 42 patients, Bourne ${ }^{[16]}$ found that the main etiologic factors are falling from a height, followed by motor vehicle 
accidents. Ayeni ${ }^{[17]}$ reported falling from heights, then simple falling, and thirdly traffic accidents as the main causes of pilon fractures.

Heim and Nasser obtained $90 \%$ good results for patients with low energy traumas caused mostly by ski injuries. These types of traumas required ORIF. They had reported that the severity of the initial traumatic episode has a significant influence on the prognosis. ${ }^{[2,18]}$ In the etiologic analysis of the 32 pilon fractures we treated, we saw a parallel with the Ayeni series. We obtained poor treatment outcomes in cases with high energy traumas, which were proportional to the severity of the trauma, soft tissue damage and patient demographics. In our series, there were no cases of pilon fractures secondary to ski injuries as was the case in the Rüedi series.

The type of the fracture (open or closed) also affected the outcomes. In open fractures, the general approach to the management consists of debridement, irrigation and external fixator application. ${ }^{[19-22]}$ For our patients with type $3(n=2)$ and $2(n=2)$ open fractures, we applied debridement, irrigation and an external fixator. We treated the remaining 9 patients with open fractures using secondary irrigation, debridement and then ORIF, as the soft tissue was suitable for this approach. These patients had type $3(n=1), 1(n=3)$, and 2 $(n=5)$ open fractures. The Teeny-Wiss ankle symptom and functional scores of patients with type 1 open fractures were good while those of the patients who were operated due to types 2 and 3 open fractures indicated fair outcomes. The Teeny-Wiss ankle scores in 2 of our patients, who were treated with an external fixator due to type 3 open fractures, were indicative of poor outcomes. In one of those patients, superficial wound infection and degenerative arthritis developed during the postoperative period. The superficial wound infection was healed with antibiotherapy and dressing. For the treatment of degenerative arthritis, glucosamine was given and the patient was monitored. The patient was informed about the fact that arthrodesis may be necessary in the future. The Teeny-Wiss scores of 2 of our patients, who were treated with an external fixator because of type 2 open fractures, were suggestive of fair outcomes. Surface wound infection also developed in these patients, and healed with dressing and antibiotherapy.

The aim in pilon fractures is to ensure a stable fixation after anatomical restoration of the injured joint and to initiate active movement of the ankle as soon as possible, while load is applied at a later time; however, this is not always possible. Primarily due to the soft tissue damage that also occurs because of the extreme trauma and defect in the joint and metaphysis, a stable osteosynthesis cannot be performed.
The timing of the surgery in pilon fractures has always been a matter of debate. Early surgery should be applied within the first 8 to 12 hours. Rüedi-Allgöwer applied early surgery for the injuries in their series, which were mostly ski injuries. Burn and colleagues applied late-term surgery (7-10 days after the incident) to their patients who had mostly high energy traumas. No significant difference between early and late surgical outcomes was found. ${ }^{[23-26]}$ The most important factor that determines the timing of the surgery is the urgent operability of the fractures. For instance, in some cases, in order to prevent skin and wound problems, the patients are not operated within the first 8-12 hours, and the surgery should be postponed for 7-10 days. We did not apply early surgery to any of our patients. In 4 of our patients, superficial wound infection developed, and was healed with dressing and antibiotherapy. For a patient with type 3 fracture, a late-term deep infection developed. After fusion of the fracture, the plate was removed and the fracture healed after debridement and irrigation.

In fractures of the distal tibia extending to the joint, where functional good results can only be achieved in $50-60 \%$ of the cases, the main treatment principles remain: anatomical open reduction and rigid internal fixation and early mobilization and principles of lateterm load-bearing of the AO/ASIF group..$^{[5,28,29]}$ When different series are examined, the success rate in type 1 and type 2 fractures is about $80 \%$, while it is only $40-50 \%$ in type 3 fractures. According to the literature, the functional results depend on the type of the fracture, and as the fracture becomes more complex, the results will also worsen. In Bourne's series with 50 patients, the results of the treatments based on principles of AO (Arbeitsgemeinschaft für Osteosythesefragen [Association for Internal Fixation Researches], which is an international organization that originated in Switzerland) were significantly good..$^{[4,30]}$ The Teeny-Wiss ankle symptom and functional score average of our type 1 patients was 87 (76-94), of type 2 patients was 85 (64-94) and of type 3 patients was 77.14 (64-96), respectively.

The external fixation of pilon fractures was first combined with open reduction by Scheck in 1965, and he reported successful results. With external fixation, the goal is to obtain reduction by using the ligamentotaxis property. However, in type 3 fractures, open reduction and minimal internal fixation of the joint might be necessary.

While in type 1 and type 2 fractures it is enough to include the tibia in the fixation procedure, in type 3 fractures, the joint has to be included as well. ${ }^{[22,31,32]}$ Otherwise, prevention of early joint movement and unfavorable healing of the cartilage might be encountered. 
We evaluated 32 pilon fractures of 31 patients treated in our clinic. Twenty-three of the fractures $(72 \%)$ were caused by high energy trauma. Thirty-two pilon fractures were evaluated as type $1(\mathrm{n}=7 ; 21.8 \%)$, $2(\mathrm{n}=11 ; 34.2 \%)$, and $3(\mathrm{n}=14 ; 44 \%)$, while 13 of them $(40.3 \%)$ were open fractures. ORIF was applied to 24 fractures and external fixation to 8 fractures. Independent of the treatment type, the functional outcomes of 18 patients with type 1 and 2 fractures were rated as excellent and good (78\%) and fair (22\%). In 14 patients with type 3 fractures, excellent and good (36\%) and fair and poor $(64 \%)$ results were obtained. In our series, which is in line with the literature, we also determined that the success rate changes with the type of the fracture.

We believe that we obtained relatively better results $(66 \%)$ with the ORIF method in the management of pilon fractures.

Pilon fractures are problematic fractures with high complication rates. The main factors that increase the complication rate and decrease the functional outcomes are the type of the fracture (open or closed), severity of soft tissue injury, location of the open and joint fractures, and severity of the trauma. ${ }^{[1,6,33]}$ The complications we encountered in our series were post-traumatic degenerative arthritis (22\%), reflex sympathic dystrophy (21\%), surface wound infection $(12.5 \%)$, late symphysis $(9 \%)$, skin necrosis $(6.25 \%)$, angulation (3\%), and late infection (3\%). Our results are in parallel with the literature findings.

Late arthritic changes are among the most important complications seen after the surgery of pilon fractures. They depend on the type of fracture, joint cartilage damage, and the type of the trauma. Our patients with post-traumatic arthritis had types $1(n=1)$, $2(n=1)$, and $3(n=5)$ fractures, respectively. In 5 of the 14 patients with type 3 fractures, post-traumatic arthritis developed. These results agree well with the literature findings.

It is known that degenerative changes occur depending on the success of the reduction. However, the damage in the joint cartilage during the trauma can cause degenerative arthritis in the late period even if a successful anatomical reduction was achieved.

To achieve successful results in the treatment of pilon fractures, a very good preoperative planning has to be made. Successful results can be achieved with atraumatic soft tissue dissection according to biological principles, anatomic restoration of the joint surface, if necessary, rigid fixation using a bone graft, movement of the ankle in the early postoperative period, and late-term load application. Especially in advanced type 3 fractures, where an anatomical joint reconstruction is impossible, and also in polytrauma- tized patients, acceptable results can be achieved with an external fixator application. However, there is no single successful treatment method that can be applied to all pilon fractures. Each fracture has to be treated individually and a treatment in compliance with surgical principles has to be well-planned.

\section{REFERENCES}

1. Reid JS. Pilon fractures update. Current Orthopaedic Practice. 2009;20:527-33.

2. Scott AT, Owen JR, Khiatani V, Adelaar RS, Wayne JS. External fixation in the treatment of tibial pilon fractures: comparison of two frames in torsion. Foot Ankle Int 2007;28:823-30.

3. Sands A, Grujic L, Byck DC, Agel J, Benirschke S, Swiontkowski MF. Clinical and functional outcomes of internal fixation of displaced pilon fractures. Clin Orthop Relat Res 1998:131-7.

4. Bourne RB, Rorabeck CH, Macnab J. Intra-articular fractures of the distal tibia: the pilon fracture. J Trauma 1983;23:5916.

5. Mast JW, Spiegel PG, Pappas JN. Fractures of the tibial pilon. Clin Orthop Relat Res 1988:68-82.

6. Boraiah S, Kemp TJ, Erwteman A, Lucas PA, Asprinio DE. Outcome following open reduction and internal fixation of open pilon fractures. J Bone Joint Surg [Am] 2010;92:34652.

7. Finsen V, Saetermo R, Kibsgaard L, Farran K, Engebretsen $\mathrm{L}$, Bolz KD, et al. Early postoperative weight-bearing and muscle activity in patients who have a fracture of the ankle. $\mathrm{J}$ Bone Joint Surg Am 1989;71:23-7.

8. Topliss CJ, Jackson M, Atkins RM. Anatomy of pilon fractures of the distal tibia. J Bone Joint Surg [Br] 2005;87:6927.

9. Giachino AA, Hammond DI. The relationship between oblique fractures of the medial malleolus and concomitant fractures of the anterolateral aspect of the tibial plafond. J Bone Joint Surg Am 1987;69:381-4.

10. Leonard M, Magill P, Khayyat G. Minimally-invasive treatment of high velocity intra-articular fractures of the distal tibia. Int Orthop 2009;33:1149-53.

11. Møller BN, Krebs B. Intra-articular fractures of the distal tibia. Acta Orthop Scand 1982;53:991-6.

12. Rhinelander FW. Tibial blood supply in relation to fracture healing. Clin Orthop Relat Res 1974:34-81.

13. Yorgancigil ME, Baran A, Yıdız M, Aksu S, Gürbüz A. Pilon kırıklarının tedavisinde ARIF'nin yeri. Acta Orthop Traumatol Turc 1994;28:87-9.

14. Sirkin M, Sanders R, DiPasquale T, Herscovici D Jr. A staged protocol for soft tissue management in the treatment of complex pilon fractures. J Orthop Trauma 2004;18:32-8.

15. Etter C, Ganz R. Long-term results of tibial plafond fractures treated with open reduction and internal fixation. Arch Orthop Trauma Surg 1991;110:277-83.

16. Bourne RB. Pylon fractures of the distal tibia. Clin Orthop Relat Res 1989:42-6.

17. Ayeni JP. Pilon fractures of the tibia: a study based on 19 cases. Injury 1988;19:109-14.

18. Bhattacharyya T, Crichlow R, Gobezie R, Kim E, Vrahas MS. Complications associated with the posterolateral approach for pilon fractures. J Orthop Trauma 2006;20:104-7.

19. Bone L, Stegemann P, McNamara K, Seibel R. External fixation of severely comminuted and open tibial pilon fractures. 
Clin Orthop Relat Res 1993:101-7.

20. Laughlin RT, Calhoun JH. Ring fixators for reconstruction of traumatic disorders of the foot and ankle. Orthop Clin North Am 1995;26:287-94.

21. Leone VJ, Ruland RT, Meinhard BP. The management of the soft tissues in pilon fractures. Clin Orthop Relat Res $1993 ;: 315-20$.

22. Murphy CP, D'Ambrosia R, Dabezies EJ. The small pin circular fixator for distal tibial pilon fractures with soft tissue compromise. Orthopedics 1991;14:283-90.

23. Bone LB. Fractures of the tibial plafond. The pilon fracture. Orthop Clin North Am 1987;18:95-104.

24. Helfet DL, Koval K, Pappas J, Sanders RW, DiPasquale T. Intraarticular "pilon" fracture of the tibia. Clin Orthop Relat Res 1994:221-8.

25. Ovadia DN, Beals RK. Fractures of the tibial plafond. J Bone Joint Surg Am 1986;68:543-51.

26. Thordarson DB. Complications after treatment of tibial pilon fractures: prevention and management strategies. J Am Acad Orthop Surg 2000;8:253-65.
27. Teeny SM, Wiss DA. Open reduction and internal fixation of tibial plafond fractures. Variables contributing to poor results and complications. Clin Orthop Relat Res 1993:108-17.

28. Rüedi T. Fractures of the lower end of the tibia into the ankle joint: results 9 years after open reduction and internal fixation. Injury 1973;5:130-4.

29. Rüedi TP, Allgöwer M. The operative treatment of intraarticular fractures of the lower end of the tibia. Clin Orthop Relat Res 1979:105-10.

30. Bourne RB. Pylon fractures of the distal tibia. Clin Orthop Relat Res 1989;240:42-6.

31. Kim HS, Jahng JS, Kim SS, Chun CH, Han HJ. Treatment of tibial pilon fractures using ring fixators and arthroscopy. Clin Orthop Relat Res 1997;334:244-50.

32. McDonald MG, Burgess RC, Bolano LE, Nicholls PJ. Ilizarov treatment of pilon fractures. Clin Orthop Relat Res 1996;325:232-8.

33. Watson JT, Moed BR, Karges DE, Cramer KE. Pilon fractures. Treatment protocol based on severity of soft tissue injury. Clin Orthop Relat Res 2000;(375):78-90. 